\title{
KREATIVITAS GURU DALAM MENINGKATKAN HASIL BELAJAR SISWA DI SMP KATOLIK SANTA ROSA SIAU TIMUR KABUPATEN SITARO
}

\author{
Temiks Merpati, Apeles Lexi Lonto, Julien Biringan \\ Jurusan PPKn FIS Unima \\ Email: lexi.lonto@unima.ac.id
}

\begin{abstract}
ABSTRAK
Penelitian ini dilatar belakangi oleh nilai dari siswa SMP Katolik Santa Rosa Siau Timur Kabupaten Sitaro terlebih khusus Kls VIII A yang sebagian besar belum mencapai kriteria ketuntasan minimal (KKM), guru belum kreatif dalam menerapkan keterampilan mengajar yang menyenangkan dimana umumnya siswa pasif dan tidak serius belajar. Metode yang digunakan dalam penelitian ini adalah penelitian kualitatif dalam bentuk naratif. Sumber data penelitian ini adalah guru yang ada di SMP Katolik Santa Rosa Siau Timur. Berdasarkan hasil penelitian tentang kreativitas guru dalam meningkatkan hasil belajar siswa pada mata pelajaran Pkn di SMP Katolik Santa Rosa Siau Timur Kabupaten Sitaro. Guru di SMP Katolik Santa Rosa Siau Timur masih belum maksimal karena dalam proses pembelajaran guru masih kurang kreativ dalam menerapkan suasana belajar yang memyenangkan. Sikap Fleksibiltas yang belum maksimal dan Sikap elaborasi yang belum maksimal diterapakan oleh Guru.
\end{abstract}

Kata Kunci: Kreativitas Guru, dan Hasil Belajar

\section{PENDAHULUAN}

Kegiatan belajar mengajar yang berlangsung di dalam kelas merupakan suatu proses interaksi antara guru dan murid, dan tentunya tidak terlepas dari berbagai permasalahan. Pada hakekatnya permasalahan yang terjadi di dalam proses belajar mengajar di dalam kelas berasal dari dua sumber yaitu guru dan murid, dimana yang menjadi prinsip permasalahannya adalah karena guru dalam praktek pengajarannya belum dapat melaksanakan kegiatan belajar mengajar dengan baik. Selanjutnya permasalahan yang bersumber pada siswa adalah karena siswa yang mengikuti kegiatan belajar mengajar belum dapat memahami dengan baik apa yang diajarkan guru, misalnya ada murid yang suka bermain saat guru menjelaskan, ada yang suka keluar masuk kelas dengan berbagai alasan dan meminta izin, dan sebagainya.

Sejalan dengan hal tersebut di atas, maka dalam undang-undang nomor 20 Tahun 2003 Tentang sistem Pendidikan Nasional pasal 3 yang menyatakan bahwa Pendidikan nasional berfungsi mengembangkan kemampuan membentuk watak serta peradaban bangsa dan bertujuan untuk berkembangnya potensi peserta didik agar menjadi individu beriman dan bertakwa kepada Tuhan yang maha Esa berakhlak Mulia, Sehat berilmu, cakap, kreatif, mandiri, dan menjadi warga negara yang demokratis serta bertanggung jawab.

Untuk mencapai sasaran yang dimaksudkan dalam undang-undang tersebut di atas, maka proses pendidikan harus berlangsung secara optimal termasuk pelaksanaan dalam proses belajar mengajar yang berlangsung di kelas, dimana sebagai inti kegiatan persekolahan merupakan proses internal. Makanya proses belajar menjar mengajar perlu memperhatikan sasaran pembentukkan watak siswa dan harus melakukannya dengan baik. Hal ini menjadi perhatian serius bagi guru dalam melakukan tugas pokoknya, dan pembelajaran yang dilakukan harus efektif, sehingga akan dapat mencapai tujuan akhir, yakni hasil belajar siswa yang optimal. Oleh sebab itu guru perlu mengembangkan pengetahuan sikap dan keterampilan siswa dalam kegaiatan belajar- 
mengajar dan menggunakan cara dan prasarana tertentu.

Berkenaan dengan pemikiran di atas, maka ditegaskan dalam UU No 14 Tahun 2005, Guru adalah pendidik professional dengan Tugas utama mendidik, mengajar, membimbing, mengarahkan, melatih, menilai, dan mengevaluasi peserta didik pada pendidikan anak usia dini, jalur pendidikan formal, pendidikan dasar, dan pendidikan menengah. Dalam kegiatan pembelajaran, Guru berperan sebagai pembimbing, pemberi motivasi, dan menjadi Fasilitator bagi siswa untuk mencapai Tujuan (Slamento, 1991:99). Peran itu juga yang mengharuskan guru untuk dapat mengajar atau memberi informasi yang sesuai bagi siswa agar memperoleh hasil belajar yang memuaskan sesuai dengan yang dirumuskan dalam kompetensi dasar.

Sehubungan dengan berbagai konsep dan permasalahan yang dikemukakan di atas, maka berdasarkan hasil pra observasi yang dilakukan di SMP Katolik Santa Rosa Siau Timur terlebih khusus di kls VIII A SMP Katolik Santa Rosa Siau Timur ditemukan bahwa nilai kriteria ketuntasan minimal (KKM) yang dihasilkan siswa hanya $40 \%$ yang mencapai nilai kriteria ketuntasan minimal (KKM).Sedangkan 60\% siswa belum mencapai kriteria ketuntasan minimal,itu didasarkan karena $60 \%$ siswa belum mencapai nilai standar kelulusan yakni nilai 80 , karena untuk standar kelulusan maka siswa haru mencapai nilai 80 namun hanya $40 \%$ siswa yang mencapai nilai yang mencapai KKM yakni nilai 80. mencermati hal tersebut maka perlu diupayakan perbaikan yang optimal dalam proses belajar mengajar sehingga bisa meningkatkan hasil belajar siswa kedepannya.

Berdasarkan berbagai pemikiran di atas, maka penulis berkeinginan untuk mengadakan penelitian ilmiah dan laporannya akan dibuat dalam bentuk skripsi dengan judul: Kreativitas guru dalam meningkatkan hasil belajar siswa pada mata pelajaran PKn di SMP Katolik Santa Rosa Siau Timur Kabupaten SITARO.

Berdasarkan identifikasi masalah di atas maka peneliti membatasi pada kreativitas guru dalam meningkatkan hasil belajar siswa dalam pembelajaran PKn di SMP Katolik Santa Rosa Siau Timur.

\section{KAJIAN PUSTAKA \\ Pengertian Kreativitas}

Kreativitas merupakan potensi yang dimiliki setiap manusia dan bukan yang diterima dari luar diri individu. Kreativitas yang dimiliki manusia, lahir bersama lahirnya manusia tersebut. Sejak lahir individu sudah memperlihatkan kecenderungan mengaktualisasikan dirinya. Dalam perkembangan kehidupan dewasa ini kreativitas merupakan faktor penting, karena kreativitas merupakan suatu kemampuan yang sangat berarti dalam proses kehidupan dari manusia.

Berdasarkan Pengertian Kreativitas menurut beberapa para ahli diatas, maka yang dimaksud dengan Kreativitas dalam Penelitian ini adalah kemampuan yang dimilki oleh seseorang atau Individu yang mempunyai inovasi lebih biak daripada sebelumnya atau kemampuan untuk menciptakan sesuatu yang baru yang lebih baik daripada sebelumnya. Sehingga lebih bermanfaat dari sebelumnya.

\section{Ciri-Ciri Kreativitas}

Kreativitas memiliki banyak ciri khas, seperti termuat dalam Pedoman Diagnostik Potensi Peserta Didik (Depdiknas 2004: 19) dalam Nurhayati (2011: 10), disebutkan ciri kreativitas antara lain: a) menunjukan rasa ingin tahu yang luar biasa, b) menciptakan berbagai ragam dan jumlah gagasan guna memecahkan persoalan, c) sering mengajukan tanggapan yang unik dan pintar, d) berani mengambil resiko, e) suka mencoba, f) peka terhadap keindahan dan segi estetika dari lingkungan.

Berdasarkan uraian tentang ciri-ciri kreativitas yang dikemukakan pada ahli di atas maka oleh peneliti menggunakan ciri-ciri kreativitas tersebut sebagai indikator yang diteliti selanjutnya, yakni ciri kognitif dan ciri non kognitif.

\section{Pengertian Guru}

Guru dalam pengertian yang terdapat pada Kamus Besar Bahasa Indonesia (1993: 288), menguraikan bahwa guru adalah orang yang pekerjaannya, mata pencahariannya, dan profesinya mengajar. Pengertian kamus inilah selanjutnya dijelaskan dalam UU RI No. 14 tahun 2005 tentang Guru dan Dosen yang 
dimaksud dengan Guru adalah pendidik professional, yang mendidik mengajar, membimbing, mengarahkan, melatih, menilai, dan mengevaluasi peserta didik pada pendidikan anak usia dini pada jalur pendidikan formal, pendidikan dasar, dan pendidikan menengah. Kemudian pengertian guru diartikan juga sebagai orang yang kerjanya mengajar atau memberikan pelajaran di Sekolah

Berdasarkan pengertian guru menurut para ahli di atas, maka yang dimaksud dengan guru dalam penelitian ini adalah seseorang atau Individu yang mempunyai tugas mengajar, membimbing, mengarahkan, menilai dan mengevaluasi peserta didik, yang mempunyai akhlak yang baik berdasarkan kemampuan yang dimiliki atau mata pelajaran yang dikuasai.

\section{Konsep Hasil Belajar}

Keberhasilan dalam belajar tidak terlepas dari cara belajar yang diterpakan dalam proses belajar itu sendiri. Motivasi intrinsic meliputi rasa percaya diri (Self-Confidence) dan harga diri pembelajaran itu sendiri (Self Esteem) dan motivasi ekstrinsik berpengaruh besar pada hasil belajar seseorang. Hasil belajar yang memuaskan dipengaruhi oleh ruang belajar, guru, metode belajar dan mengajar, begitupun sebaliknya.

\section{Tujuan Penilaian Hasil Belajar}

Sudjana (2005) mengutarakan tujuan penilaian hasil belajar sebagai berikut:

a) Mendeskripsikan kecakapan belajar siswa sehingga dapat diketahui kelebihan dan kekurangannya dalam berbagai bidang studi atau meta pelajaran yang ditempuhnya. Dengan pendeskripsian kecakapan tersebut dapat diketahui pula posisi kemampuan siswa dibandingkan dengan siswa lainnya.

b) Mengetahui keberhasilan proses pendidikan dan pengajaran di sekolah, yakni seberapa jauh keefektifannya dalam mengubah tingkah laku siswa ke arah tujuan pendidikan yang diharapkan. -Menentukan tindak lanjut hasil penilaian, yakni melakukan perbaikan dan penyempurnaan dalam hal program pendidikan dan pengajaran serta sistem pelaksanaannya. c) Memberikan pertanggungjawaban (accountability) dari pihak sekolah kepada pihak-pihak yang berkepentingan.

\section{Jenis Penilaian}

Penilaian jika ditinjau dari fungsinya, oleh Sudjana (2005) membagi penilaian ke dalam empat jenis, yaitu: Penilaian formatif adalah penilaian yang dilaksanakan di akhir program belajar-mengajar untuk melihat tingkat keberhasilan proses belajar mengajar itu sendiri. Penilaian sumatif adalah penilaian yang dilaksanakan di akhir unit program, yaitu akhir caturwulan, akhir semester, dan akhir tahun. Penilaian ini berorientasi pada produk bukan pada proses. Kemudian penilaian diagnostik adalah penilaian yang bertujuan untuk melihat kelemahan-kelemahan siswa serta faktor penyebabnya. Penilaian selektif adalah penilaian yang bertujuan untuk keperluan seleksi, misalnya ujian saringan masuk ke lembaga pendidikan tertentu. Penilaian penempatan adalah penilaian yang dilakukan untuk mengetahui keterampilan prasyarat yang diperlukan bagi suatu program belajar dan penguasaan belajar seperti yang diprogramkan sebelum memulai kegiatan belajar untuk program itu, (Sudjana, N. (2005).

Berdasarkan Uraian tentang ciri-ciri penilaian hasil belajar di atas maka peneliti menggunakannya sebagai Indikator yang diteliti Selanjutnya Yakni Penilaian Sumatif, Diagnostik, Selektif, Penempatan.

\section{Pengertian Siswa}

Pengertian siswa merupakan pelajar yang duduk dimeja belajar setrata sekolah dasar maupun menengah pertama (SMP), sekolah menengah keatas (SMA). Siswa-siswa tersebut belajar untuk mendapatkan ilmu pengetahuan dan untuk mencapai pemahaman ilmu yang telah didapat dunia pendidikan. Siswa atau pesetra didik adalah mereka yang secara khusus diserahkan oleh kedua orang tuanya untuk mengikuti pembelajaran yang diselengarakan di sekolah, dengan tujuan untuk menjadi manusia yang berilmu pengetahuan, berketrampilan, berpengalaman, berkepribadian, berakhlak mulia, dan mandiri (Kompas, 1985).

Berdasarkan Pengertian siswa menurut para ahli di atas, Maka yang dimaksud dengan 
siswa dalam Penelitian ini adalah Seseorang atau Individu yang mempunyai kemampuan Kognitif, Afektif, Psikomotor, yang mempunyai tahaptahap yaitu terdiri dari Sekolah Dasar, Sekolah menengah Pertama, Sekolah Menengah Atas.

\section{Konsep Pendidikan Kewarganegaraan (PKn)}

PKn adalah nama dari suatu mata pelajaran yang terdapat dalam kurikulum sekolah. PKn berusaha membina perkembangan moral anak didik sesuai dengan nilai-nilai Pancasila, agar dapat mencapai perkembangan secara optimal dan dapat mewujudkan dalam kehidupannya sehari-hari, (M. Daryono, dkk. 1998:1). Kemudian menurut Kerr, citizenship or civics education is construed broadly to encompass the preparation of young people for their roles and responsibilities as citizens and, in particular, the role of education (through schooling, teaching, and learning) in that preparatory process, (Winataputra dan Budimansyah, 2007: 4).

Terjemahan Dari definisi Kerr tersebut yang dapat dijelaskan bahwa pendidikan kewarganegaraan itu dirumuskan secara luas yang telah mencakup proses penyiapan generasi muda untuk bisa mengambil peran \& tanggung jawab sebagai warga negara, serta secara khusus, peran pendidikan ini termasuk didalamnya persekolahan, pengajaran \& belajar, dalam proses penyiapan warga negara tersebut.

Berdasarkan Pengertian PKn menurut para ahli di atas, maka yang dimaksud dengan PKn dalam Penelitian ini adalah: Pendidikan Moral yang bertujuan agar siswa menjadi manusia yang berasaskan Pancasila dan berkarakter menjalankan kewajiban warga Negara sesuai UUD 1945.

\section{METODE PENELITIAN}

Dalam penelitian ini peneliti menggunakan metode penelitian deskritif kualitatif dalam bentuk naratif, Menurut Bogdan dan Tylor sebagaimana yang dikutip oleh Lexi Moleong menyebutkan bahwa yang dimaksud dengan deskriptif kualitatif adalah metode yang digunakan untuk menganalisa data dengan mendeskripsikan data melalui bentuk kata-kata tertulis atau lisan dari orang-orang dan perilaku yang diamati.Peneliti menggunakan jenis penelitian deskriptif kualitatif naratif, dikarenakan ada beberapa pertimbangan di antaranya adalah: penelitian ini bersifat menggambarkan, menguraikan suatu hal dengan apa adanya, maksudnya adalah data yang dikumpulkan adalah berupa kata-kata atau penalaran, gambar, dan bukan angka-angka. Sumber data dalam penelitian ini adalah guruguru yang ada di SMP Katolik Santa Rosa Siau Timur, yakni guru PKn, guru bahasa Indonesia, guru Matematika, guru Penjasorkes. Dalam penelitian ini Metode pengumpulan data yang digunakan adalah: Wawancara, Observasi, Dokumentasi. Teknik analisis data dalam penelitian ini adalah: Reduksi data, Penyajian Data, Penarikan kesimpulan dan verifikasi.

\section{HASIL PENELITIAN DAN PEMBAHASAN Kreativitas Guru}

Menurut Tami Munandar (2009: 12), bahwa kreativitas adalah hasil interaksi antara individu dan lingkungannya, kemampuan untuk membuat kombinasi baru, berdasarkan data, informasi, atau unsur-unur yang sudah ada atau dikenal sebelumnya, yaitu semua pengalaman dan pengetahuan yang telah diperoleh seseorang selama hidupnya baik itu di lingkungan sekolah, keluarga, maupun dari lingkungan masyarakat.

\section{a) Sikap Fleksibilitas}

Fleksibiltas kemampuan untuk beradaptasi dan bekerja dengan efektif dalam situasi yang berbeda, dan dengan berbagai individu atau kelompok. Berdasarkan hasil penelitian yang telah dijelaskan sebelumnya ternyata peneliti mengamati dalam pelaksanaan pembelajaran masih ada sebagian siswa yang masih saja ribut pada saat pelajaran berlangsung itu diakibatkan karena sebagian siswa yang bercerita dalam kelas pada saat mata pelajaran berkangsung dan apabila siswa ribut maka guru akan menegur siswa tersebut. Masih kurang mahir guru dalam menggunakan fasilitas pembelajaran misalnya dalam pengoperasian LCD.

\section{b). Sikap Elaborasi}

Elaborasi adalah penggarapan secara tekun dan cermat. Selanjutnya berdasarkan hasil penelitian yang telah dijelaskan sebelumnya ternyata Peneliti mengamati dalam pelaksanaan Pembelajaran masih Kurangnya dalam kemampuan membuat Rencana Pelaksanaan 
Pembelajaran. Indikasinya ialah kurikulum yang dipakai tidak diperbaharui atau dikembangkan dengan Baik. Hal ini mengakibatkan Guru dengan bebasnya mengajarkan apa yang ada dipikirannya dan tidak memperdulikan kurikulum yang seharusnya digunakan dalam proses belajar mengajar. Dan dalam kegiatan belajar mengajar terlihat guru sering memberikan motivasi untuk membangun karakter yang baik maupun disiplin Moral

\section{c). Memberi Motivasi}

Memberi motivasi adalah pemberian proses yang menjelaskan intensitas, arah, dan ketekunan seorang individu untuk mencapai tujuannya. Berdasarkan hasil penelitian yang telah dijelaskan sebelumnya ternyata Peneliti mengamati dalam pelaksanaan Pembelajaran Guru sudah mampu memberikan tanggapan yang positif yang berkaitan dengan materi Pelajaran dipelajari Guru sering memberikan motivasi untuk membangun karakter yang baik maupun disiplin.

\section{d). Kepribadian}

Kepribadian merupakan keseluruhan sikap, ekspresi,perasaan, temprarmen,ciri khas dan juga perilaku seseorang. Maka berdasarkan hasil penelitian yang telah dijelaskan sebelumnya ternyata kepribadian yang ditemukan peneliti dalam pelaksanaan pembelajaran bahwa guru sudah mampu memberikan atau menyuruh kepada siswa untuk menyuruh tingkah laku yang baik dan positif terhadap siswa.

\section{e). Kreativ}

Kreativ adalah skill untuk menyelesaikan sebuah kasus yang memberi kesempatan kepda setiap personal untuk berkreasi untuk memunculkan ide-ide baru /adaptif yang memilki fungsi dan kegunaan secara menyeluruh untuk berkembang. (Widyatun 1999). Berdasarkan hasil penelitian yang telah dijelaskan sebelumnya ternyata peneliti mengamati dalam pelaksanaan pembelajaran bahwa guru belum mampu menerapkan suasana belajar yang mengajar yang menyenangkan. Sehingga di dalam kelas banyak siswa yang ribut, di dalam kelas banyak siswa yang bercerita dengan sesama siswa sehingga proses belajar masih kurang menyenangkan, guru tidak ada inisiatif untuk memberikan games dalam pelaksanaan pembelajaran dan dalam mengajar guru sudah mampu memberikan atau menyuruh kepada siswa untuk melaksanakan tingkah laku yang baik dan positif terhadap siswa. Dan belum mampu menerpakan suasana belajar mengajar dengan baik, tidak ada insiatif dari guru untuk melaksanakan pembelajaran di luar kelas.

\section{Hasil Belajar}

\section{a). Penilaian Sumatif}

Penilaian sumatif adalah penilaian yang dilaksanakan di akhir unit program, yaitu akhir caturwulan, akhir semester, dan akhir tahun. Penilaian ini berorientasi pada produk bukan pada proses. Berdasarkan hasil penelitian yang telah dijelaskan sebelumnya ternyata peneliti mengamati bahwa pada saat berakhirnya 1 semester akan memberikan ujian Semester untuk menjadi evaluasi bagi siswa dan untuk menjadi patokan untuk nilai akhir yang dicapai oleh siswa, dan akan melaksankan ujian tengah semester pada 3 bulan pertama dan ujian harian pada saat memyelesaikan 1 materi.

\section{b). Penilaian Diagnostik}

Penilaian diagnostik adalah penilaian yang bertujuan untuk melihat kelemahan-kelemahan siswa serta faktor penyebabnya. Berdasarkan hasil penelitian yang telah dijelaskan sebelumnya ternyata Peneliti mengamati bahwa guru dapat mengamati kelemahan yang ada pada diri siswa dalam proses belajar-mengajar setelah melihat kelemahan yang ada dalam diri siswa lalu Guru melakukan pendekatan untuk menyelesaikan kelemahan tersebut.

\section{c). Penilaian Selektif}

Penilaian selektif adalah penilaian yang bertujuan untuk keperluan seleksi, misalnya ujian saringan masuk ke lembaga pendidikan tertentu. Berdasarkan hasil penelitian yang telah dijelaskan sebelumnya ternyata peneliti mengamati bahwa guru melihat dan menilai kemampuan yang dimilki oleh siswa dalam hal pengetahuaan karena bisa dilihat dari proses pembelajaran bagi siswa yang lebih aktif atau mempunyai kemampuan yang tinggi bisa 
dikatakan memilki kemampuan dalam hal penegetahuan.

\section{d). Penempatan}

Penilaian penempatan adalah penilaian yang dilakukan untuk mengetahui keterampilan prasyarat yang diperlukan bagi suatu program belajar dan penguasaan belajar seperti yang diprogramkan sebelum memulai kegiatan belajar untuk program itu. Berdasarkan hasil penelitian yang telah dijelaskan sebelumnya ternyata peneliti mengamati bahwa ternyata guru belum mampu melihat keterampilan yang dimiliki oleh siswa karena di dalam kelas siswa hanya membaca buku dan mengerjakan tugas.

\section{KESIMPULAN}

\section{Kesimpulan}

Berdasarkan hasil analisis data penelitian yang dilakukan maka dapat disimpulkan bahwa: 1. Sikap Fleksibiltas yang dimilki oleh guru di SMP Katolik santa Rosa Siau Timur masih belum maksimal karena ketika dalam kegiatan belajar masih ada siswa yang ribut dan masih ada guru yang belum mahir dalam menggunak media pembelajaran mislanya LCD.

2. Sikap Elaborasi yang dimiliki guru PKn masih belum maksimal karena guru menyiapkan RPP menunggu kurikulum untuk diperbaharui.

3. Memberi Motivasi yang dimilki oleh guru PKn sudah berlangsung dengan baik karena dalam kegaiatan pembelajaran guru PKn selalu memberi Motivasi yang membangun untuk siswa
4. Kepribadiaan yang dimilki oleh guru PKn sudah dilakukan dengan baik karena guru mampu menyuruh tingkah laku yang baik dalam kehidupan bermasyarakat

5. Kreativ yang dimilki oleh guru PKn masih belum maksimal karena guru tidak ada inisiatif untuk melaksanakan kegiatan pembelajaran di luar kelas.

6. Guru PKn di SMP Katolik Santa Rosa Siau Timur sudah maksimal dalam melaksanakan Penilaian Sumati, Diagnostik, Selektif, dan Penempatan.

\section{Saran}

1. Guru lebih meningkatkan lagi kemapuan dalam sikap flesksiblitas untuk suasana pembelajarn yang lebik baik, tidak ada siswa yang ribut, dan lebih ditingkatkan lagi kemampuan dalam menggunakan media pembelajaran misalnya LCd.

2. Guru lebih meningkatkan lagi kemampuan dalam sikap Elaborasi dengan selalu wajib mempersiapkan RPP dalam setiap jam mengajar.

3. Kemampuan dalam memberi motivasi diharapakn tetap diperthankan untuk pembelajaran yang lebih baik.

4. Kepribadian yang dimilki oleh guru diharapkan dipertahankan dan lebih baik lagi apabila ditingkatkan

5. Kreativ yang dimilki oleh guru lebih ditingkatkan lagi agar ada suasana pembelajaran yang menyengankan.

\section{DAFTAR PUSTAKA}

Rohani, A. (2007). Pengelolaan Pengajaran. Jakarta: PT Rineka Cipta.

Semiawan, C. R. (2009). Memupuk Bakat dan Kreativitas Siswa Sekolah Menegah. Jakarta: Gramedia.

Supriadi, D. (1994). Kreativitas Kebudayaan dan Perkembangan Iptek. Bandung: Alfabeta.

Moleong, L. (2000). Metode Penelitian Kualitatif. Bandung: Remaja Rosdakarya.

Syah, M. (2008). Psikologi Pendidikan dengan Pendekatan Baru. Bandung: PT Rosda Karya.

Daryono, dkk. (1998). Pengantar Pendidikan Pancasila dan Kewarganegaraan Jakarta: Rineka Cipta.

Rifai, M. (2016). Sosiologi Pendidikan. Jogjakarta: Ar-Ruzz Media.

Ngalimun, dkk. (2013). Perkembangan dan Pengembangan Kreativitas. Yogyakarta: Aswaja Pressindo.

Slamento, (2003). Belajar dan Faktor-faktor yang mempengaruhinya. Jakarta: Rineka Cipta. 
Sukarti, 1986 Prediksi Keberhasilan, Yogyakarta: UGM Press.

Sudjana, N. (2005). Penilaian hasil proses belajar mengajar. Bandung: PT Remaja Rosdakarya.

Sugiyono, (2014). Metode Penelitian Kuantitatif, Kualitatif dan R\&D Bandung: Alfabeta.

Sugiyono, (2012). Metode penelitian pendidikan pendekatan Kuantitatif, Kualitatif dan R\&D, Alfabeta, Bandung

Danim, S. 2014 Perkembangan Peserta Didik. Bandung: Alfabeta.

Rusyan, T. (1992) pendekatan dalam proses belajar mengajar. Bandung: Remaja Rosdakarya Munandar, U. (2002). Anak Unggul Berotak Prima. Jakarta: PT. Gramedia.

Munandar, U. (1992). Mengembangkan Bakat dan Kreativitas Anak Sekolah. Jakarta: PT. Gramedia. http//kebugaran dan jasmani.blog spot

http://www. Spengetahuan.com

http://Buku Tips menjadi Guru inspirtif, ptkcontoh.com,

http://infodanpengertian.blogspot.co.id/2016/02/pengertian-siswa-menurut-para-ahli.html

Penilaian hasil proses belajar mengajar. Bandung: PT Remaja Rosdakarya. 